\title{
Grand challenges in plant nutrition
}

\author{
Nicolaus von Wirén* \\ Molecular Plant Nutrition, Department of Physiology and Cell Biology, Leibniz-Institute for Plant Genetics and Crop Plant Research, Gatersleben, Germany \\ *Correspondence: vonwiren@ipk-gatersleben.de
}

As a scientific discipline, plant nutrition stands on two legs. One leg is anchored in plant physiology and explains the fundamental processes underlying and regulating the acquisition, allocation, and utilization of mineral elements in plants. The other leg is deeply rooted in an applied, problem-oriented context, explaining the use and action of fertilizers and the cycling of mineral elements in agricultural plant production. This creates completely different expectations on what plant nutrition shall accomplish. On the one hand, biochemical basics underlying nutritional processes shall be described down to the molecular level, such as the differential selectivity of membrane transporters for nutrients or signaling functions of mineral nutrients in plant development. On the other hand, large parts of the society, from farmers to policy makers, expect plant nutritionists to develop concepts that allow further enhancements in crop yield and quality while increasing nutrient efficiency and reducing nutrient losses from crop production systems. These different expectations generate a quite heterogenic community of plant nutritionists spanning from pure molecular biologists that never go beyond the gene or protein level to agronomists, who move between the whole-plant and field scales. Even though molecular and agronomic oriented plant nutritionists are aware of their mutual dependency, they tend to separate into different scientific subgroups using different publication organs. As one of the consequences, definitions and scientific standards set by these sub-communities of plant nutritionists tend to develop into different directions, becoming apparent for example in the choice and justification of plant growth conditions or the application of statistical methods to setup experiments and evaluate data. Thus, the plant nutrition community certainly faces one grand challenge in bridging the gap between basic and applied science and building an integrated community that tackles the open questions in a common effort.
Recent progresses in physical and analytical chemistry, molecular biology and genetics have opened a large array of opportunities for plant nutritionists to address questions going beyond the fundamental processes of the uptake and utilization of mineral elements. Based on the most common workhorse in elemental analysis, inductively coupled plasma-mass spectrometry (ICP-MS), significant improvements have been made to increase the sensitivity and number of simultaneously determined elements, to decrease the sample size required for analysis and for gaining additional information on the determined elements. These technical improvements include laser ablation-coupled ICP-MS to determine the subcellular distribution of elements (Conn and Gilliham, 2010) or size exclusion/ion pairing chromatography for a stoichiometric determination of elemental compositions in plant samples (Lee et al., 2009; Persson et al., 2009). ICP-MS is also employed to study the ionome, defined as the total mineral element content of a plant or plant organ. Determining these mineral element profiles in mutant populations or natural accession lines has proven successful not only for the identification of transporter genes and their relation to site-specific nutrient profiles in the landscape (Baxter et al., 2010), but also of genes encoding structural barriers for nutrient uptake by roots (Baxter et al., 2009). MulticollectorICP-MS has been introduced to show that naturally occurring isotopes may fractionate differently within plants according to the strategy employed for nutrient acquisition (von Blankenburg et al., 2009). Advances have also been made in the identification of metal binding forms that are trafficked over long distances in plants through the use of high-resolution ESI-FTICR-MS or HPLC-ESI-TOFMS (Weber et al., 2006; Rellán-Alvarez et al., 2010). These analytical techniques are increasingly complemented by imaging approaches describing the tissue and cell-type specific distribution of mineral elements using high-definition synchrotron X-ray fluorescence for example (Punshon et al., 2009; Lombi et al., 2011). The combination of these and alternative imaging techniques with molecular and physiological approaches can generate more integrated pictures on how individual gene products affect the distribution of mineral elements at the tissue or cellular level (Kim et al., 2006; Tauris et al., 2009). A major challenge here is to combine these imaging and molecular approaches at the level of single cells (Conn et al., 2011) to identify specific functions of mineral elements in different cell types.

Advances in plant nutrition also profited from rapidly improving tools in crop genomics. Screening, QTL mapping, and transgenic approaches in rice have identified $\mathrm{Na}$ exporters in the xylem that decrease the $\mathrm{Na}$ load to the shoot and thereby increase salt tolerance (Ren et al., 2005), or aquaporin-type silicon transporters whose polar localization in the root endodermis generate a passive Si flux into the root stele (Ma et al., 2006, 2007). In sorghum and maize, field-based mapping studies have revealed $\mathrm{Al}$ tolerance mechanisms that rely on organic acid exudation mediated by different transporter types (Magalhaes et al., 2007; Maron et al., 2010), and B tolerance in barley could be attributed to $B$ transporters that export B out of root cells (Sutton et al., 2007). Unexpectedly, a specific transporter for $\mathrm{Al}$ at the plasma membrane of rice roots was recently discovered that contributes to Al tolerance probably by favoring $\mathrm{Al}$ deposition in the vacuole for the benefit of a lower Al load in the root apoplast (Xia et al., 2010). Although these examples emphasize that membrane transporters represent major control points for adequate nutrient uptake and allocation in the plant, their biotechnological use for enhanced nutrient accumulation in the plant or biofortification of seeds still remains in many instances without success.

Remarkable is also the progress made in wheat, where a NAC-type transcription factor has turned out to control leaf senescence 
and thereby $\mathrm{N}, \mathrm{Fe}$, and $\mathrm{Zn}$ retranslocation from leaves to seeds (Uauy et al., 2006). This example demonstrates the importance of previous classical plant nutritional studies that started with the evaluation of seed $\mathrm{Zn}$ concentrations in different wheat cultivars and their ancestors (Cakmak et al., 2004). This led to further work that uncovered a tight correlation between seed $\mathrm{Zn}$ and seed protein concentrations in parental lines and their recombinant inbred lines and later allowed mapping and cloning of this senescence-regulating transcription factor (Uauy et al., 2006). Such examples should encourage more systematic measurements of nutrient-related traits in breeding or mapping populations of crop species, which may be best performed in close cooperation between plant nutritionists and plant geneticists.

Future advances in plant nutrition will also be brought about by a better understanding of root responses to the variable supply of soil nutrients. Elaborated growth systems and more reliably quantified root traits now describe how the nutrient supply shapes root architecture. A prominent example for this is the directed growth of lateral roots toward nutrient-enriched patches (Drew, 1975), which appears to be a nutrient-specific or even nutrient formspecific response. For instance, the localized supply of ammonium mainly stimulated lateral root initiation, while nitrate promoted particularly the elongation of lateral roots (Zhang et al., 1999; Lima et al., 2010). The nitrate effect has recently been shown to rely on an altered auxin distribution in the root tip and was explained by the dual function of a nitrate transporter working as an auxin transporter under certain nutritional situations (Krouk et al., 2010). This is an amazing example of how plant nutrition can interfere with the transport and homeostasis of phytohormones and thus with root architecture. Whether this type of knowledge will also serve to better exploit nutrient reserves in soils and thus may contribute to improved fertilizer use efficiencies in agricultural plant production systems still needs to be investigated.

The continuous increase in world population and highly variable growth conditions due to global climate change strengthen the need to boost agricultural plant productivity. Currently, the major challenges are to enhance crop yields in more resource-efficient cropping systems and to stabilize plant development and yield formation under less predictable growth conditions (Reynolds et al., 2009). In both cases plant nutrition will and must play an important role since increasing yield potentials in crops are mostly related with higher nutrient demands. However, intensive agriculture faces serious environmental concerns from the society that have already begun to lead to more rigorous regulations and constraints in fertilization practices. A straightforward step out of this dilemma may be the introduction of knowledge-based fertilization concepts extending also to those countries where excess fertilizer application is still part of common practice (Ju et al., 2009). A key to sustainable agricultural plant nutrition management systems in any country is the reduction of nutrient budgets at the farm level, particularly for nitrogen and phosphorus. This requires (i) innovative strategies to reduce $\mathrm{N}$ losses in animal production systems at all levels from the lifestock production facilities to the storage of organic manure and finally its application to field crops; and (ii) a better distribution of excess nutrients from regions with high livestock densities to regions with less nutrients. The latter is of particular importance for P not only for environmental reasons, but also to make better use of a worldwide limited resource. In this context particular attention should be devoted to developing processes that allow the P from municipal wastes to be recycled free of plant-available organic and inorganic toxicants. Another promising strategy is the development and introduction of precision fertilization techniques for site-specific crop management, however this requires the real-time measurement of the soil or plant nutrient status. The rapid measurement of soil macronutrients during or before soil management may rely on optical diffuse reflectance sensing or electrochemical sensing based on ion-selective electrodes or ion-selective field effect transistors (Kim et al., 2009). By contrast, the crop N status can be indicated in real time by remote sensing techniques on the proviso that visible light reflected from the canopy correlates with the leaf $\mathrm{N}$ status (Haboudane et al., 2002). In future the use of satellite-derived hyperspectral images will address more precisely the spatial and temporal variability in the $\mathrm{N}$ nutritional status of leaves and thus particularly improve mid-season $\mathrm{N}$ management. In this regard, new satellites providing hyperspectral images at high spatial and temporal resolution will provide a great opportunity for improved nutrient-specific fertilization concepts in precision agriculture (Cohen et al., 2010). It may therefore be expected that precision fertilization will become more dependent on technical improvements in optical imaging over short and long ranges, their geo- and bioinformatic processing and the delineation of the spectral data to the plant nutrient status and to chemical plant properties.

These are only a few examples emphasizing how plant nutrition needs to integrate over different scientific disciplines to meet the societal requests for productive, sustainable, and environmentally sound plant production. The other side of this coin is that plant nutritionists face a challenging time with great opportunities for novel developments and exciting discoveries.

\section{REFERENCES}

Baxter, I., Brazelton, J. N., Yu, D., Huang, Y. S., Lahner, B., Yakubova, E., Li, Y., Bergelson, J., Borevitz, J. O., Nordborg, M., Vitek, O., and Salt, D. E. (2010). A coastal cline in sodium accumulation in Arabidopsis thaliana is driven by natural variation of the sodium transporter AtHKT1;1. PLoS Genet. 6, e1001193. doi: 10.1371/journal.pgen.1001193

Baxter, I., Hosmani, P. S., Rus, A., Lahner, B., Borevitz, J. O., Muthukumar, B., Mickelbart, M. V., Schreiber, L., Franke, R. B., and Salt, D. E. (2009). Root suberin forms an extracellular barrier that affects water relations and mineral nutrition in Arabidopsis. PLoS Genet 5, e1000492. doi: 10.1371/journal.pgen.1000492

Cakmak, I., Torun, A., Millet, E., Feldman, M., Fahima, T., Korol, A., Nevo, E., Braun, H. J., and Ozkan, H. (2004). Triticum dicoccoides: an important genetic resource for increasing zinc and iron concentration in modern cultivated wheat. Soil Sci. Plant Nutr. 50, 1047-1054.

Cohen, Y., Alchanatis, V., Zusman, Y., Dar, Z., Bonfil, D. J., Karnieli, A., Zilberman, A., Moulin, A., Ostrovsky, V., Levi,A., Brikman, R., and Shenker, M. (2010). Leaf nitrogen estimation in potato based on spectral data and on simulated bands of the VEN $\mu \mathrm{S}$ satellite. Precis. Agric. 11, 520-537.

Conn, S. J., and Gilliham, M. (2010). Comparative physiology of elemental distributions in plants. Ann. Bot 105, 1081-1102.

Conn, S. J., Gilliham, M., Athman, A., Schreiber, A. W., Baumann, U., Moller, I., Cheng, N. H., Stancombe, M. A., Hirschi, K. D., Webb, A. A., Burton, R., Kaiser, B. N., Tyerman, S. D., and Leigh, R. A. (2011). Cell-specific vacuolar calcium storage mediated by CAX1 regulates apoplastic calcium concentration, gas exchange, and plant productivity in Arabidopsis. Plant Cell 23, 240-257.

Drew, M. C. (1975). Comparison of the effects of a localized supply of phosphate, nitrate, ammonium and potassium on the growth of the seminal root system, and the shoot, in barley. New Phytol. 75, 479-490. 
Haboudane, D., Miller, J. R., Tremblay, N., Zarco-Tejada, P. J., and Dextraze, L. (2002). Integrated narrow-band vegetation indices for prediction of crop chlorophyll content for application to precision agriculture. Remote Sens. Environ. 81, 416-426.

Ju, X. T., Xing, G. X., Chen, X. P., Zhang, S. L., Zhang, L. J., Liu, X. J., Cui, Z. L., Yin, B., Christie, P., Zhu, Z. L., and Zhang, F. S. (2009). Reducing environmental risk by improving $\mathrm{N}$ management in intensive Chinese agricultural systems. Proc. Natl. Acad. Sci. U.S.A. 106, 3041-3046.

Kim, H. J., Sudduth, K. A., and Hummel, J. W. (2009). Soil macronutrient sensing for precision agriculture. J. Environ. Monit. 11, 1810-1824.

Kim, S. A., Punshon, T., Lanzirotti, A., Li, L., Alonso, J. M., Ecker, J. R., Kaplan, J., and Guerinot, M. L. (2006). Localization of iron in Arabidopsis seed requires the vacuolar membrane transporter VIT1. Science 314, 1295-1298.

Krouk, G., Lacombe, B., Bielach, A., Perrine-Walker, F., Malinska, K., Mounier, E., Hoyerova, K., Tillard, P., Leon, S., Ljung, K., Zazimalova, E., Benkova, E., Nacry, P., and Gojon, A. (2010). Nitrateregulated auxin transport by NRT1.1 defines a mechanism for nutrient sensing in plants. Dev. Cell 18, 927-937.

Lee, S., Jeon, U. S., Lee, S. J., Kim, Y. K., Persson, D. P., Husted, S., Schjørring, J. K., Kakei, Y., Masuda, H., Nishizawa, N. K., and An, G. (2009). Iron fortification of rice seeds through activation of the nicotianamine synthase gene. Proc. Natl. Acad. Sci. U.S.A. 106, 22014-22019.

Lima, J. E., Kojima, S., Takahashi, H., and von Wirén, N. (2010). Ammonium triggers lateral root branching in Arabidopsis in an AMMONIUM TRANSPORTER1;3-dependent manner. Plant Cell 22, 3621-3633.

Lombi, E., Smith, E., Hansen, T.H., Paterson, D., de Jonge, M. D., Howard, D. L., Persson, D. P., Husted, S., Ryan, C., and Schjoerring, J. K. (2011). Megapixel imaging of (micro)nutrients in mature barley grains. J. Exp. Bot. 62, 273-282.
Ma, J. F., Tamai, K., Yamaji, N., Mitani, N., Konishi, S., Katsuhara, M., Ishiguro, M., Murata, Y., and Yano, M. (2006).A silicon transporter in rice. Nature 440, 688-691.

Ma, J. F., Yamaji, N., Mitani, N., Tamai, K., Konishi, S. Fujiwara, T., Katsuhara, M., and Yano, M. (2007). An efflux transporter of silicon in rice. Nature 448, 209-212.

Magalhaes, J. V., Liu, J., Guimarães, C. T., Lana, U. G., Alves, V. M., Wang, Y. H., Schaffert, R. E, Hoekenga, O. A., Piñeros, M. A., Shaff, J. E., Klein, P. E., Carneiro, N. P., Coelho, C. M., Trick, H. N., and Kochian, L. V. (2007).A gene in the multidrug and toxic compound extrusion (MATE) family confers aluminum tolerance in sorghum. Nat. Genet. 39, 1156-1161.

Maron, L. G., Piñeros, M.A., Guimarães, C. T., Magalhaes, J. V., Pleiman, J. K., Mao, C., Shaff, J., Belicuas, S. N., and Kochian, L. V. (2010). Two functionally distinct members of the MATE (multi-drug and toxic compound extrusion) family of transporters potentially underlie two major aluminum tolerance QTLs in maize. Plant J. 61, 728-740.

Persson, D. P., Hansen, T. H., Laursen, K. H., Schjoerring, J. K., and Husted, S. (2009). Simultaneous iron, zinc, sulfur and phosphorus speciation analysis of barley grain tissues using SEC-ICP-MS and IP-ICP-MS. Metallomics 1, 418-426.

Punshon, T., Guerinot, M. L., and Lanzirotti, A. (2009). Using synchrotron X-ray fluorescence microprobes in the study of metal homeostasis in plants. Ann. Bot. 103, 665-672.

Rellán-Alvarez, R., Giner-Martínez-Sierra, J., Orduna, J., Orera, I., Rodríguez-Castrillón, J. A., García-Alonso, J. I., Abadía, J., and Alvarez-Fernández, A. (2010) Identification of a tri-iron(III), tri-citrate complex in the xylem sap of iron-deficient tomato resupplied with iron: new insights into plant iron long-distance transport. Plant Cell Physiol. 51, 91-102.

Ren, Z. H., Gao, J. P., Li, L. G., Cai, X. L., Huang, W., Chao, D. Y., Zhu, M.Z., Wang, Z. Y., Luan, S., and Lin, H. X. (2005). A rice quantitative trait locus for salt tolerance encodes a sodium transporter. Nat. Genet. 37, 1141-1146.
Reynolds, M., Foulkes, M. J., Slafer, G. A., Berry, P., Parry, M. A., Snape, J. W., and Angus, W. J. (2009). Raising yield potential in wheat. J. Exp. Bot. 60, 1899-1918. Sutton, T., Baumann, U., Hayes, J., Collins, N. C., Shi, B. J., Schnurbusch, T., Hay, A., Mayo, G., Pallotta, M., Tester, M, and Langridge, P. (2007). Boron-toxicity tolerance in barley arising from efflux transporter amplification. Science 318, 1446-1449.

Tauris, B., Borg, S., Gregersen, P.L., and Holm, P. B. (2009). A roadmap for zinc trafficking in the developing barley grain based on laser capture microdissection and gene expression profiling. J. Exp. Bot. 1333-1347.

Uauy, C., Distelfeld, A., Fahima, T., Blechl, A., and Dubcovsky, J. (2006). A NAC Gene regulating senescence improves grain protein, zinc, and iron content in wheat. Science 314, 1298-1301.

von Blankenburg, F., von Wirén, N., Gülke, M., Weiss, D., and Bullen, T. (2009). Fractionation of metal stable isotopes by higher plants. Elements 5, 375-380.

Weber, G., von Wirén, N., and Hayen, H. (2006). Analysis of iron(II)/iron(III) phytosiderophore complexes by nano-electrospray ionization Fourier transform ion cyclotron resonance mass spectrometry. Rapid Commun. Mass Spectrom. 20, 973-980.

Xia, J., Yamaji, N., Kasai, T., and Ma, J. F. (2010). Plasma membrane-localized transporter for aluminum in rice. Proc. Natl. Acad. Sci. U.S.A. 107, 18381-18385.

Zhang, H., Jennings, A., Barlow, P. W., and Forde, B. G. (1999). Dual pathways for regulation of root branching by nitrate. Proc. Natl. Acad. Sci. U.S.A. 96, 6529-6534.

Received: 09 March 2011; accepted: 10 March 2011; published online: 21 March 2011.

Citation: von Wirén N (2011) Grand challenges in plant nutrition. Front. Plant Sci. 2:4. doi: 10.3389/fpls.2011.00004 This article was submitted to Frontiers in Plant Nutrition, a specialty of Frontiers in Plant Science.

Copyright (C) 2011 von Wirén. This is an open-access article subject to an exclusive license agreement between the authors and Frontiers Media SA, which permits unrestricted use, distribution, and reproduction in any medium, provided the original authors and source are credited. 